\title{
Semantic Features of Hungarian Neologisms With the Prefix Be: Analysis of Some Frequently Used Verbs (e.g., bevállal) ${ }^{1}$
}

\author{
Réka Sólyom
}

\begin{abstract}
The present paper deals with the semantic features of three Hungarian neologisms (becéloz, betámad, bevállal), and analyzes their semantic structures with the help of the Conceptual Integration Theory (Blending Theory). The words analyzed are verbs that have been used with the prefix be in recent years, although they are wellestablished with other prefix(es). As be is one of the oldest Hungarian prefixes, it has likely gained new function(s) in these cases. To substantiate this claim, data was gathered from two questionnaires (in 2010 and in 2014), and informants' answers concerning meaning and style were analyzed. These data can help the survey in other fields too: firstly, they can help model the processes of understanding (or misunderstanding) of these neologisms, secondly, they can help model the semantic structures of the verbs within the framework of Blending Theory. Thirdly, these data can help indicate language use at a given point in time, from a synchronic viewpoint.
\end{abstract}

Keywords: Neologisms, Be-prefix, Conceptual Integration (Blending) Theory, Questionnaire, Semantic Structure

Biography: Réka Sólyom, who received her PhD in 2012, is a Lecturer at the Károli Gáspár University of the Reformed Church in Hungary (Faculty of Humanities, Budapest, in the Institute of Hungarian Linguistic, Literary and Cultural Studies, Department of Hungarian Linguistics.) She is a member of the Research Group in Stylistics at Eötvös Loránd University, Budapest. Her research interests are stylistics, semantics (especially cognitive semantics), rhetoric, and questions concerning the teaching of Hungarian as a foreign language. She has published several articles on the semantic and stylistic features of neologisms, processes of language change and issues in the teaching of rhetoric, stylistics, and communication. Her monograph titled A mai magyar neologizmusok szemantikája ('Semantics of Present-day Hungarian Neologisms') has been published in 2014 at Akadémiai Kiadó, and she has written a book for Communication Practice titled Kommunikációs gyakorlatok at Károli Gáspár University in 2014.

${ }^{1}$ The present paper, which is a fundamentally revised and updated version of Sólyom 2012a, has been supported by grant K 81315 (Cognitive Stylistic Research) of OTKA (Hungarian Scientific Research Fund). 
Sólyom, Réka. "Semantic Features of Hungarian Neologisms With the Prefix Be: Analysis of Some Frequently Used Verbs (e.g., bevállal)." Hungarian Cultural Studies. e-Journal of the American Hungarian Educators Association, Volume 7 (2014): http://ahea.pitt.edu DOI: 10.5195/ahea.2014.148

This paper deals with a phenomenon that has become more and more frequent in presentday Hungarian, namely the use of the prefix be ('in, into') with Hungarian verbs previously found with other prefixes, such as $m e g, f e l$ or $e l$. Nowadays the two different forms of such verbs (i.e. the same stem with two different prefixes) are both found, but with noteworthy differences in meaning as well as register (style). It follows that these "new" verbs (their occurrence and their register) often attract the attention of Hungarian speakers, many of whom regard them as neologisms. It is important to emphasize that there can be important differences between language users' opinions and attitudes, and even between the ways they understand (or misunderstand) these novel phenomena. However, people can usually recognize new words and phrases in language use, and in the long run it is the language users who decide whether to employ these neologisms. Accordingly, this paper has multiple goals: firstly, it considers the "older" meanings and functions of be, with regard to its present-day use. Secondly, it exemplifies some verbs with be from present-day language use (becéloz, betámad, bevállal), and considers their semantic characteristics. This study is a part of a bigger project begun in 2005, since which time more than 1300 informants have completed questionnaires concerning various types of neologisms.

The present paper is based on answers gathered from questionnaires. The hypothesis of the paper is linked to the informants' answers: with the help of their answers the process of understanding or misunderstanding a neologism can be modeled and analyzed. In the case of the neologisms analyzed, graphic representations will be given based on the Mental Spaces and Conceptual Integration Theory (Blending Theory) of Fauconnier (1994) and Fauconnier and Turner (1998). Language users' answers concerning the meaning of the analyzed neologisms and informants' attitudes can be examined, based on answers to the questions concerning style and personal opinions about neologisms.

Although many definitions of "neologism" have been offered (see Sachwörterbuch der Literatur (1989), A Dictionary of Stylistics (1990), Dictionnaire des termes littéraires (2001), Stilisztikai lexikon (2004)), there remain problems of defining and understanding the notion since it is very difficult and sometimes impossible to identify the precise moment in time when a change occurs between the two states when language users still consider a linguistic phenomenon a neologism and when they feel that it is no longer a neologism (for theories of linguistic change see Keller 1985 and Croft 2000).

Language users' opinions about new words or phrases can be influenced by many factors, such as the details considered relevant by the speaker; the aspects of the conceptualization emphasized; the social relationship between the speaker and the addressee; the speaker's beliefs concerning the addressee's knowledge of the context and the intention that is being expressed (Langacker 1987: 65).

Some neologisms can be called "trendy" (Lehrer 2003: 369) and in such cases, the speaker is not really interested in helping the addressee discover the term's meaning in the quickest possible manner but rather to increase the mental effort required of the addressee, and to thus attract his attention (e.g. bocsoda, garfieldozik, vidámparkol). To some extent, verbs with be fall into this category as well.

As the problem of defining neologisms suggests, such a definition is needed that reflects the relative and language-user orientated features of the novel linguistic phenomena. In the present paper, the following definition of neologism will be used: a neologism is a linguistic phenomenon, sometimes with a novel structure, that in a given situation is considered by the addressee to have a novel meaning and/or a novel style, according to the addressee's prior or 
Sólyom, Réka. "Semantic Features of Hungarian Neologisms With the Prefix Be: Analysis of Some Frequently Used Verbs (e.g., bevállal)." Hungarian Cultural Studies. e-Journal of the American Hungarian Educators Association, Volume 7 (2014): http://ahea.pitt.edu DOI: 10.5195/ahea.2014.148

imagined prior experiences and expectations. These meaning and style attributions are dynamic, and may be subject to change according to a scale, depending on the above mentioned features, even in the case of the same language user (Sólyom 2014: 19).

As mentioned above, Conceptual Integration Theory (also called Blending Theory) as elaborated by Fauconnier (1994) and Fauconnier and Turner (1998) will be used in the analyses of the verbs examined. While the theories of conceptual metaphor and metonymy deal with relationships between fixed pairs of mental representations (see Kövecses and Radden 1998: 38; Panther and Thornburg 2003: 2), Conceptual Integration Theory can connect more than two mental representations. Consequently, the processes depicted in a blend can represent a dynamic structure seen in the process of meaning construction (Tolcsvai Nagy 2010: 96). As a result, meaning can be understood in the given context, and can be represented according to the intentions of the participants in the communicational process, in a dynamic structure. During this process, so-called space-builders (Fauconnier 1994: 16; Tolcsvai Nagy 2010: 98) help build up small conceptual units or mental spaces, and this can help with the processes of understanding and forming further reactions (Kövecses and Benczes 2010: 160). Mental spaces that are linked together are structured by frames and cognitive models, and so they can be changed as the discourse unfolds (Fauconnier and Turner 1998: 137).

There are three important types of spaces in a blend that have to be mentioned here: they are the so-called input spaces, the optional generic space and the blended space. "In blending, the selection of input structures is selective, that is, not all the elements from the input spaces get to be projected" (Benczes 2006: 53). That is why the blended space usually contains selected aspects from the input spaces (Coulson and Oakley 2003: 55). As already mentioned, mental spaces can be characterized by great flexibility: "(...) a mental space is a short-term construct informed by the more general and more stable knowledge structures associated with a particular domain" (Grady, Oakley, and Coulson 1999: 102). Applying Conceptual Integration can be fruitful if we want to represent the semantic structure of verbs with prefixes - and not only in the case of neologisms (Tolcsvai Nagy 2013: 231-232). Therefore in the present paper this opportunity will be exploited in the semantic analysis of these verbs (see Sólyom 2012b, 2013).

$\mathrm{Be}$ is one of the oldest prefixes in the Hungarian language. Its meaning is the opposite of $k i$ ['out']. "Their functions often developed analogously, so that they are a kind of mirror-image of each other. However, the use of be is more limited, its occurrence is more rare, it has fewer functions, than the other prefixes discussed and it has strayed less from its original meaning, with its perfective role relatively recent (see Soltész 1959: 107). In present-day Hungarian, the use of $b e$ can be observed with a number of verbs. These novel forms often live side by side, having more meanings or different prepositions. It is worth asking “ $\ldots$ why do these forms come into existence: through the realization of potential forms appropriate to the rules of the system, or merely through the breaking of its rules, or maybe the restructuring of the system's rules?" (Ladányi 2007: 260).

In Hungarian, be has many meanings and functions: according to Soltész, it can refer to various situations (after the description I give the literal as well as the approximate meaning of the verbs in English): 1) movement into an enclosed space (bemegy, ['go in']), 2) creating an enclosed space (becsuk, ['shut in' 'enclose, shut']), 3) covering a space or a surface with the action or with the result of the action (bemázol, ['paint in', '(completely) paint']), 4) perfectivity (besötétedik, ['get dark']), 5) verbs involving jurisdiction (bevádol, ['accuse in', 'arraign, accuse']), 6) verbs connected to eating and drinking where something gets into the 'inside' of a human being (bereggelizik, ['breakfast in', 'eat a hearty breakfast']), 7) some verbs that have a 
Sólyom, Réka. "Semantic Features of Hungarian Neologisms With the Prefix Be: Analysis of Some Frequently Used Verbs (e.g., bevállal)." Hungarian Cultural Studies. e-Journal of the American Hungarian Educators Association, Volume 7 (2014): http://ahea.pitt.edu DOI: 10.5195/ahea.2014.148

radically different meaning with be than without it (beéri valamivel, ['make do with something', where ér is 'reach, etc']; Soltész 1959: 116-121). According to Strukturális magyar nyelvtan ['Structural Hungarian Grammar'], be has three main functions: 1) direction, 2) completeness, totality, 3) saturation (Kiefer and Ladányi 2000: 484-93). Nevertheless, in spite of the richness of possible meanings of be, it should be emphasized that their process of semantic change has not come to an end, not even in the case of the so-called ancient Hungarian prefixes (Pátrovics 2002: 481-482).

The present paper investigates responses to three neologisms with be, collected from informants in 2010 and 2014. The first questionnaire was completed by four groups of informants in spring 2010 (see Sólyom 2012a), and the second by two groups of informants (secondary school students and university students) in spring 2014. Although the two questionnaires asked questions concerning the same words in the case of becéloz (literally ['aim in'], meaning approximately ['aim at']), betámad (literally ['attack in'], meaning approximately ['attack']), and bevállal (literally ['undertake in'], meaning approximately ['undertake']), neither the contextualizing sentences nor the questions that followed them were exactly the same.

The survey focuses on informants' responses concerning 1) the meaning of the neologism (semantic features, understanding processes, misunderstanding processes, synonyms, circumlocutions for the neologisms), as well as 2) their opinions about the neologisms (attitude, opinions concerning style and register). Certain differences between the answers of informants in 2010 and in 2014 will be highlighted, as four years can bring important changes in the case of neologism use. As mentioned, graphic representations of the verbs analyzed will also be given.

\section{Becéloz}

Although the novel meaning of this verb (literally meaning ['aim in']) is not attested in the standard, it has been used in oral use for about ten years. During the last few years it has become widespread in language use: the Google search engine found 2950 examples of it on July 23rd 2010, and on April 19th 2014, the number of examples was 21800. This verb does not occur in the standard Magyar Értelmezö Kéziszótár ['The Concise Dictionary of the Hungarian Language']. In the questionnaires conducted in 2010 and in the spring of 2014 informants could read the verb in sentences from the Internet, where the verb meant 'aim at' someone: "The production ... aims at every age group" [A rendezés ... becéloz minden korosztályt $]$, and "The Opera House will have in its sights both schools and teachers next season" [Iskolákat és tanárokat is becéloz az Opera a következö évadban]. From the informants' answers in the questionnaires it was clear that having read the verb in the contexts provided, they emphasized its metaphorical meanings (e.g. 'aim at', 'recommend'). In 2010, 68\% of secondary school students and $100 \%$ of university students wrote that the verb meant 'aimed at someone', 'it is intended for someone'. Moreover, $21 \%$ of the former group and $19 \%$ of the latter group wrote that 'it has an impact upon someone', or 'it is interesting, enjoyable' (informants had the opportunity to write several synonyms or circumlocutions). However, in 2014, some changes in the questionnaire answers were noticeable: more secondary school students and fewer university students wrote that the meaning of the verb was 'aimed at someone' or 'it is intended for someone', $81 \%$ of secondary school students and $88 \%$ of university students felt that 'aim at' was the meaning of the verb. As for the meaning 'it has an impact upon someone', 'it is interesting, enjoyable', fewer informants felt that this was the meaning of the verb (11\% and $1 \%$ of informants, respectively). 
The informants' answers can be diagrammed as follows:

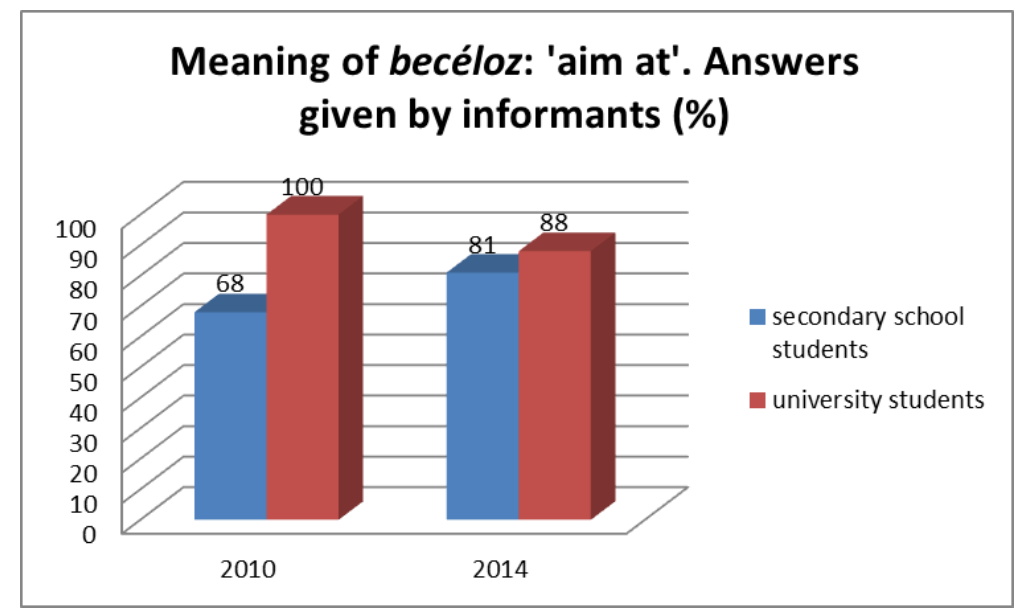

Diagram 1: Becéloz as 'aim at'

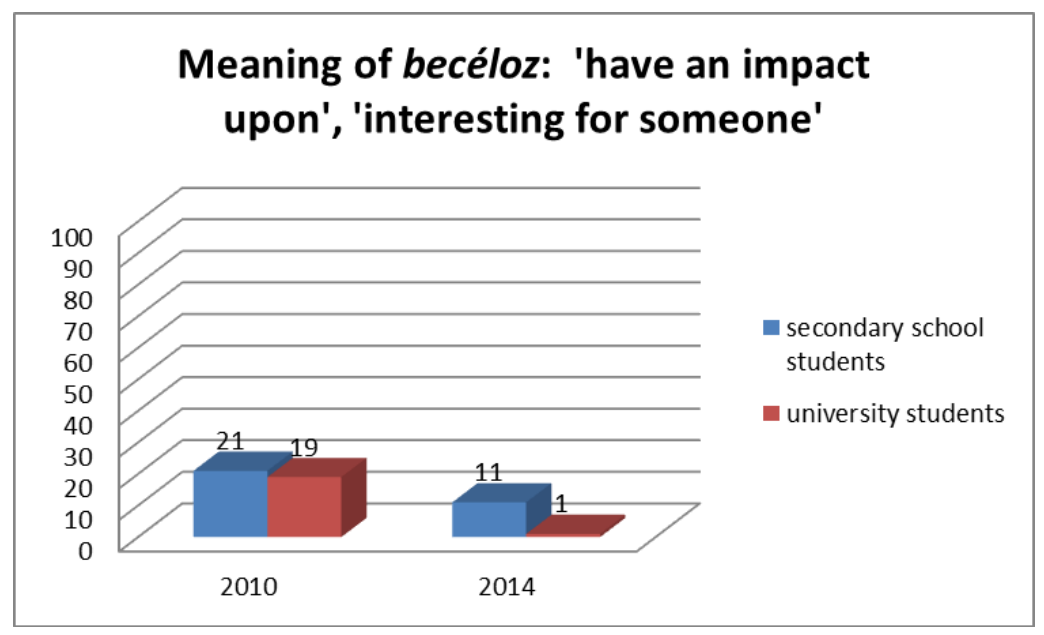

Diagram 2: Becéloz as 'have an impact upon'

It should be noted that there is an existing word, megcéloz in standard Hungarian which means 'aim at'. Megcéloz has the the same root as céloz, ['aim'], but with the prefix, meg, which refers to the aim (direction) and perfectivity of the action. Taking into account informants' answers concerning the neologism becéloz in the given sentences, a question arises at this point: what is the difference between the older megcéloz and the newer becéloz? There must be some differences, as the novel form has come into existence, and is becoming more widespread. As mentioned earlier, it seems that the verb becéloz has developed additional senses beside the one noted: attacking a physical object and attacking someone's feelings. It is useful to take a look at the informants' responses in the 2014 questionnaire, concerning their opinions about the effects 
of becéloz in the sentences given as examples in the questionnaire. Some felt that the usage of be made the verb more precise than the usage of meg: many informants mentioned the older form megcéloz when they read the novel verb in the given sentence. They also considered it "more dynamic" and hence drew the attention of readers more. One informant even wrote that in the case of the Opera House's advertisement they felt as if someone had aimed an arrow at the audience. Based on the answers given by these two groups of informants, the processes that play a role in the understanding of this neologism can be sketched and represented graphically with the help of the Conceptual Integration Theory (Blending Theory). It is best to start with the semantic features of the prefix be, and of the older verb megcéloz. The semantic features of the prefix be and the verb megcéloz will be represented in the so-called input spaces. As these input spaces contain ' entirely different characteristics, there will not be a generic space (which is facultative), but the characterizing features of the two input spaces will be projected directly into the blended space. Thus, the important difference mentioned by the informants between the older megcéloz and the newer becéloz, viz. the precise and total aim at someone's opinion (choice, decision) can be emphasized (cf. Ladányi 2007: 275). Graphically, the above mentioned features can be represented as follows (Sólyom 2014: 109):

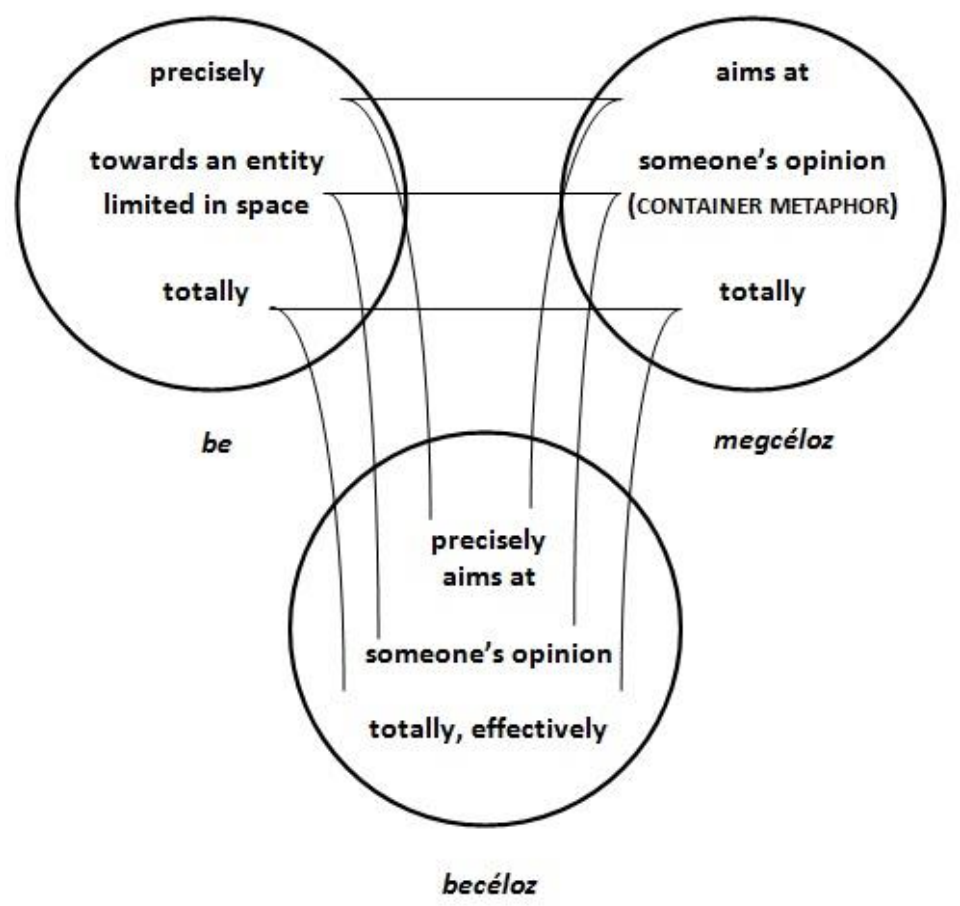

Figure 1: Blend of becéloz

As for informants' opinions and attitudes about the style of becéloz, important data can be gleaned from the questionnaires. In the 2010 questionnaire, informants were asked about the use of becéloz: they had to say whether or not they liked the word in the given context. Their answers can be seen in Diagram 3: 


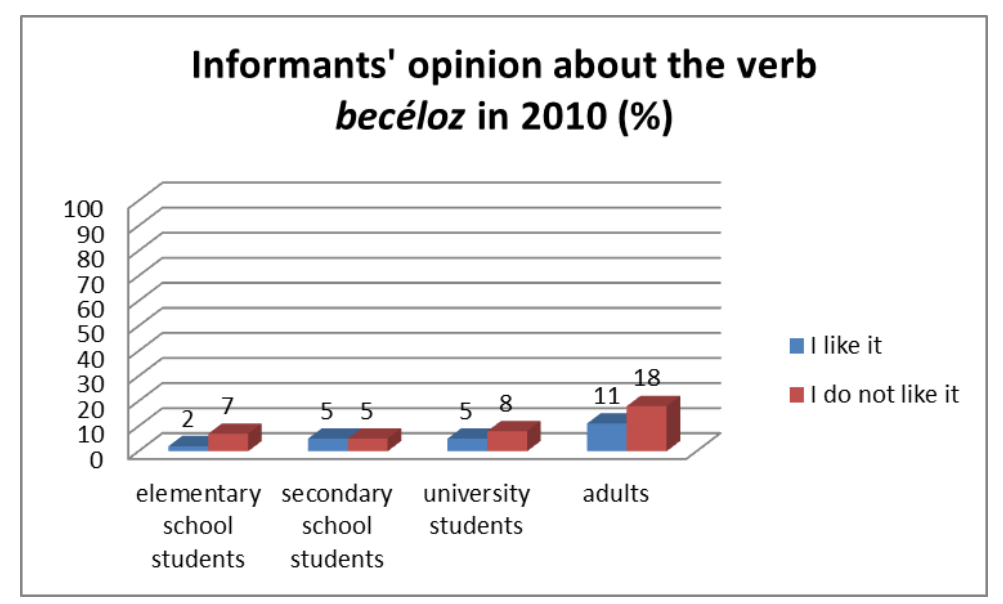

Diagram 3: Opinions about becéloz

In 2014, two groups of informants were asked to give their views about the verb becéloz. Fifty percent of the university students and 33\% of the secondary school students wrote that they felt the use of becéloz in the given context negative, rude, or inappropriate. It is significant that more university students felt the usage to be ruder or inappropriate than secondary school students, showing that they may be more sensitive to the stylistic effect of the new prefix, which may be because 1) they have had more prior exposure to the use of be,2) they are older and consequently do not find these kinds of neologisms as "trendy" (Lehrer 2003) as do the secondary school students, 3) as these university students are students in the faculty of arts, they may be more conscious of their language use than the other group.

Here is a selection of the more interesting responses from university students concerning the style of becéloz:

- I find it weird, more like school slang,

- it is slangy, I don't understand why the prefix meg had to be changed,

- I think that the speaker is uneducated,

- it is disrespectful.

These can be compared with some responses from secondary school students:

- it is flippant,

- it is not appropriate to this serious text (i.e. the Opera House text that contained the examined verb),

- it is uneducated.

Fifty percent of the university students wrote that they felt that the verb was informal or slang, which means that they do not consider it rude or uneducated. In the case of secondary school students, $26 \%$ of the informants failed to respond to this question. Those who did, however, also mentioned its slanginess and some of them added that the style of this verb was modern and/or funny. 
Sólyom, Réka. "Semantic Features of Hungarian Neologisms With the Prefix Be: Analysis of Some Frequently Used Verbs (e.g., bevállal)." Hungarian Cultural Studies. e-Journal of the American Hungarian Educators

Association, Volume 7 (2014): http://ahea.pitt.edu DOI: 10.5195/ahea.2014.148

\section{Betámad}

This verb (literally meaning 'attack in', approximately meaning 'attack') is not attested in most of the dictionaries, but has gained several meanings in Hungarian in the last few years. It should be said that, just as in the case of becéloz, this verb has another, older form, with the prefix meg (megtámad). Nevertheless, many occurrences of betámad can be found in present-day Hungarian. (The Google search engine found 5,970 results for the verb on April 24th 2014.) In the questionnaires, two different senses of betámad could be read by informants. In 2010, the following sentence was given: "I think that if you are aimed in by someone, you will defend yourself" [Szerintem, ha téged betámad valaki, akkor te is megvéded magad!]. In 2014, another sense of the neologism was given in the questionnaire: “... some [radio] stations were trying to scare people by claiming that winter would attack in with snow on Sunday" [... korábban egyes állomások azzal riogattak, hogy vasárnap havazással még betámad a tél...]. As Ladányi (2007, 275) points out, in addition to the notion of 'result, perfectivity' that can also be found in meg, overexaggeration or completeness play a role in the case of the be prefix, consequently, betámad gains the meaning of 'attack intensely, heavily'.

In the first example, betámad could be understood either as a physical or a verbal attack (from this viewpoint, it functioned just like megtámad). In the second, a natural phenomenon (the weather) had an impact upon people and threatened them; consequently, a wholly different meaning was elaborated. Interestingly, in the case of the situations given in the sentences in the questionnaires, either the verb with meg prefix, or the root of the verb (támad) alone could be used. However, both writers of the sentences given as examples chose the neologism in order to emphasize the intensity of the depicted phenomena and so the threatening circumstances. In the 2010 questionnaire, there were no secondary school and university students who did not write a synonym or a circumlocution for the verb betámad. Most informants focused on the fact that the meaning of this neologism is 'attack' someone verbally or physically. There were some answers that reflected the verb's intentionality and "wildness", and, consequently, informants wrote that the result of betámad can even be an unpleasant situation, insulting or accusing someone of something. In the 2014 questionnaire in response to the question if the informants felt the threatening meaning of the verb betámad in reference to the weather, both the secondary school and the university students gave identical responses, with $44 \%$ understanding the verb to refer to threatening or even dangerous circumstances, while $56 \%$ did not. The latter group simply gave synonyms or circumlocutions that explained that bad weather was on its way. The former group of informants, who referred to threat, emphasized that the attack of the bad weather will be sudden, unexpected, or dangerous. The responses can be seen in the following diagram: 


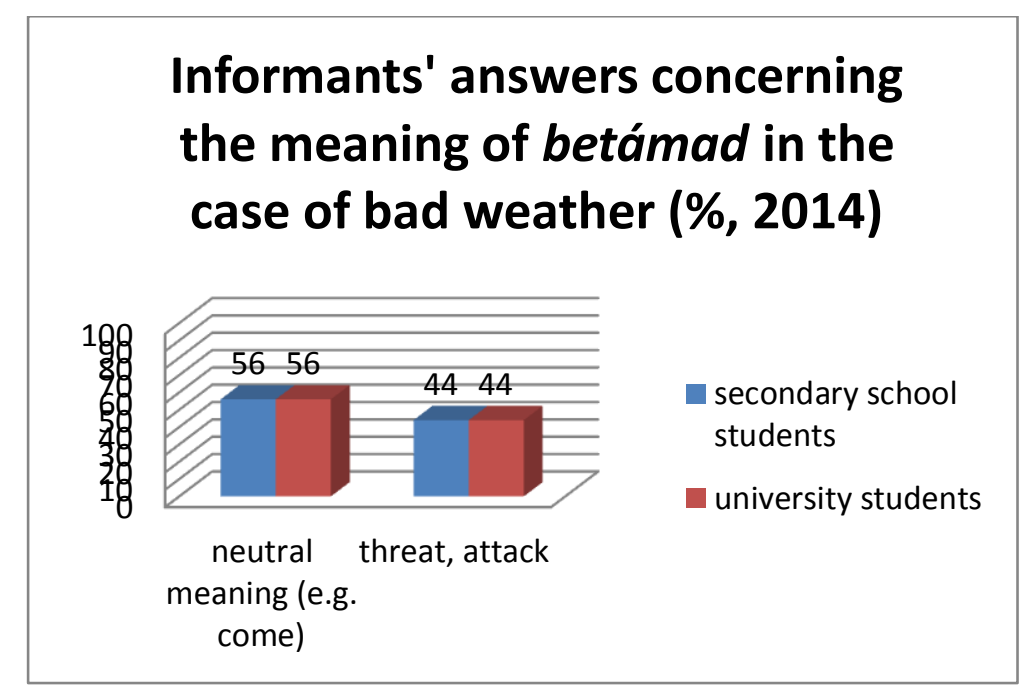

Diagram 4: Meanings of betámad

Based on informants' answers and on those processes that we have witnessed in the case of becéloz (viz. the neologism's relationship to the older type of the verb, usually with meg prefix), we can sketch the semantic structures of the neologism betámad in two meanings, using Conceptual Integration Theory. In the case of the first meaning (physical or verbal attack), the new prefix (be) can be linked with the already existing form, megtámad ['attack']. The latter here is understood metaphorically, where, according to the conceptual metaphor theory (LakoffJohnson 1980 or Kövecses 2005, 2010), the human SOUL IS A CONTAINER plays important role. ${ }^{2}$. It is the entity (viz. the human soul or body) that is attacked precisely and totally. The intensity, preciseness, and the totality are better expressed and emphasized by the new prefix, $b e$. As can be seen in Figure 2, both the meaning of the root of the verb and the functions of be prefix play their role in making up the meaning of the neologism (cf. Sólyom 2014: 103):

\footnotetext{
${ }^{2}$ I would like to thank Réka Benczes for calling my attention to the importance of CONTAINER metaphors in these instances.
} 


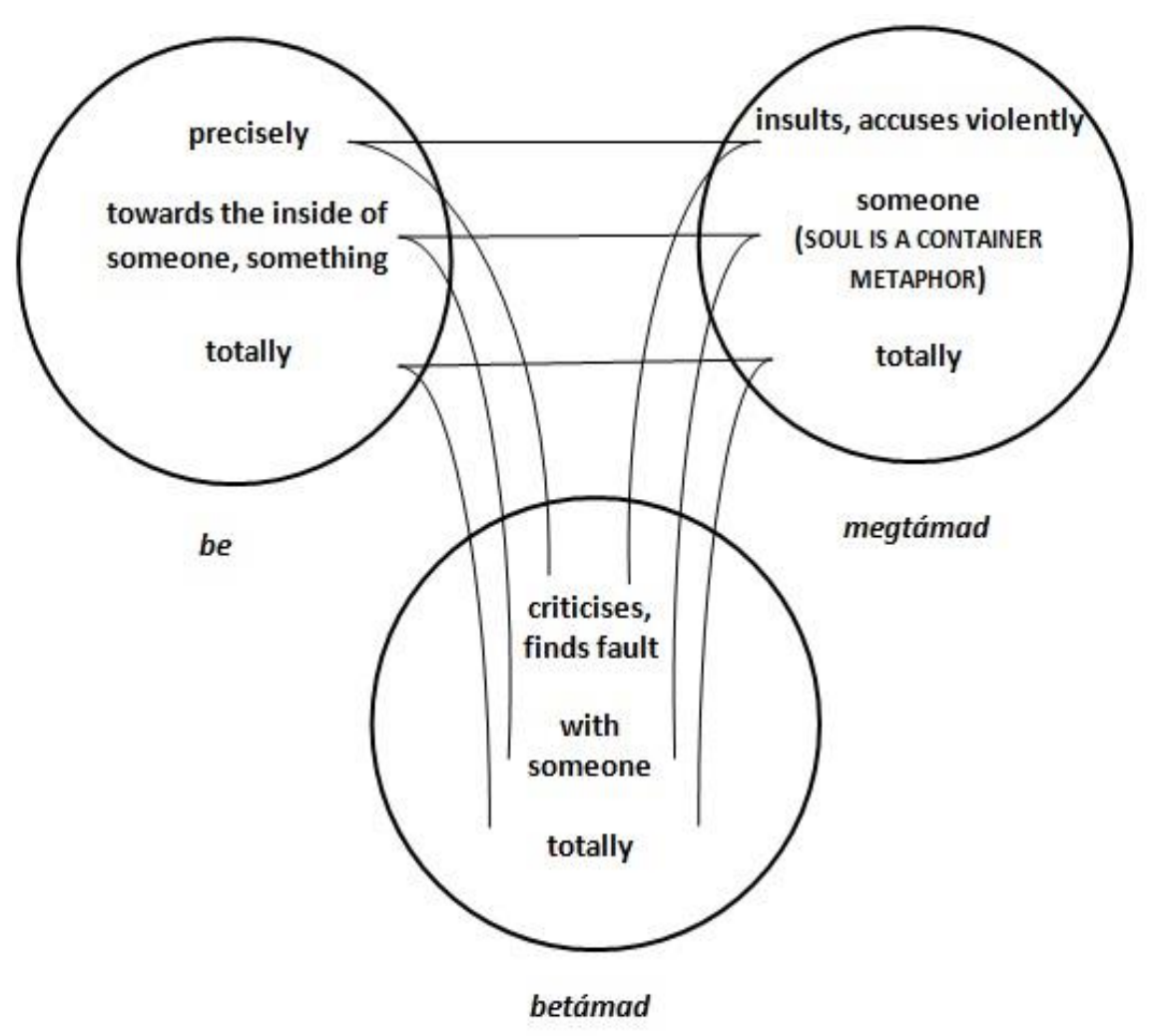

Figure 2: Blend of betámad ( $1^{\text {st }}$ meaning)

As for the meaning 'aiming someone in' of betámad, we can start again from the preciseness, direction, and the totality implied by the prefix $b e$. However, in the case of this meaning, these features have to be linked with the meanings of megtámad ['attack'] and feltámad ['start up, resurrect'] referring to unexpectedness. Because feltámad can be used with words about weather, language users often associate the phenomena of weather with this verb (as informants did in the questionnaire). Here, in the case of betámad, BODY or PLACE IS A CONTAINER metaphor plays role again, as these are the things that are threatened by bad weather.

The unexpected and threatening features of meg- or feltámad associated with weather are again summarized in the blend. When the perfectivizing function of the prefix be are added to the meaning of meg-or feltámad, the new meaning of betámad is ready, making up an effective and more energetic word than the former megtámad or feltámad (see Ladányi 2007, 275). These features are summarized in Figure 3 (Sólyom 2014: 105): 
Sólyom, Réka. "Semantic Features of Hungarian Neologisms With the Prefix Be: Analysis of Some Frequently Used Verbs (e.g., bevállal)." Hungarian Cultural Studies. e-Journal of the American Hungarian Educators Association, Volume 7 (2014): http://ahea.pitt.edu DOI: 10.5195/ahea.2014.148

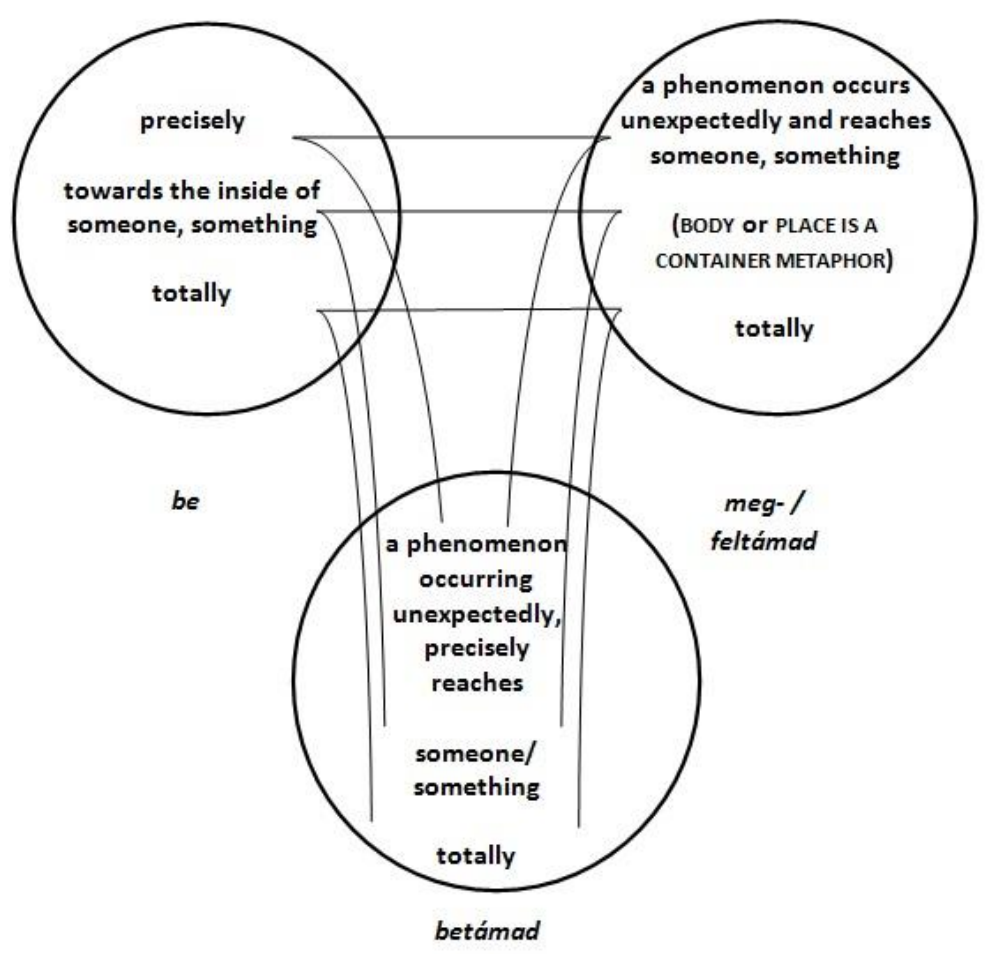

Figure 3: Blend of betámad ( $2^{\text {nd }}$ meaning)

The chart below illustrates the two new meanings of betámad. In the case of the first meaning of the neologism, relevant answers were gathered from four groups of informants in 2010. No more than $2 \%$ of the informants said that they liked the usage of betámad in the given example sentence, and 10-16\% did not like it at all (Diagram 5):

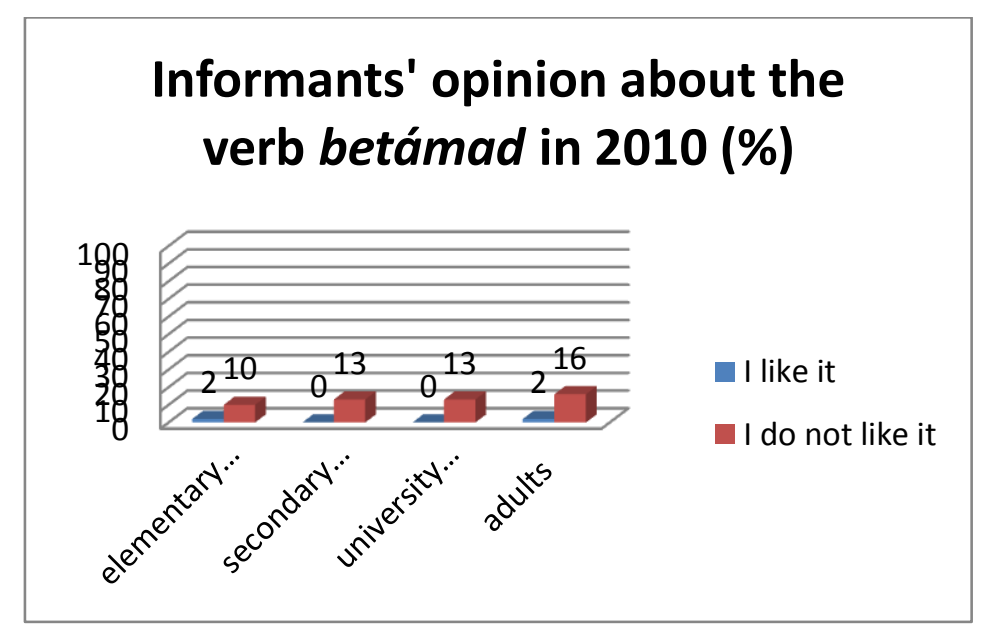

Diagram 5: Opinions about betámad 
Sólyom, Réka. "Semantic Features of Hungarian Neologisms With the Prefix Be: Analysis of Some Frequently Used Verbs (e.g., bevállal)." Hungarian Cultural Studies. e-Journal of the American Hungarian Educators Association, Volume 7 (2014): http://ahea.pitt.edu DOI: 10.5195/ahea.2014.148

In 2014, $37 \%$ of secondary school students and $44 \%$ of university students wrote that they felt the usage of betámad to be negative and strange, with some using harsher judgments, such as careless, too modern, or even rude. In contrast to the majority group, some informants wrote that the prefix $b e$ "strengthened" the effect of the verb: it was more effective, dynamic, or even funny. It is interesting that in the case of this verb only $12 \%$ of the informants referred to it as slang but, on the contrary, they tended to emphasize its effectiveness and dynamism.

\section{Bevállal}

This verb (literally meaning 'undertake in', meaning 'undertake') like the previous becéloz and betámad, cannot be found in most of the dictionaries. Bevállal probably occurred earlier than the two other analyzed verbs, as it is discussed by Somogyi in 2003. Just as in the case of becéloz and betámad, there is another verb, elvállal (or even yet another, felvállal) in Hungarian that refers to a situation when someone undertakes something, usually something that is difficult or extreme. It should be noted that there is an adjective formed from this verb, bevállalós ['game, enterprising'], which is in widespread and popular use in contemporary Hungarian. Some informants mentioned that they liked this adjective.

At this point, the question arises as to what kinds of differences can be found between the type of change in the case of megcéloz $\rightarrow$ becéloz, megtámad $\rightarrow$ betámad vs. elvállal $\rightarrow$ bevállal? As we can see, the latter example contains a shift from $e l$ to $b e$. As Ladányi emphasizes: the occurrence of be here is not a mistake, but, on the contrary, it has an important function: while el represents a process from a starting point towards an endpoint, be emphasizes intensity, completeness and/or beginning (Ladányi 2007, 274). It may be the case that bevállal means more than elvállal, as the former reflects the extremeness or the difficulties of a situation, and presupposes that someone who acts like this has to perform something difficult, risky, or even dangerous. If we take a look at the data gathered from informants in 2010 and in 2014, it can be seen that although the verb bevállal was given in the same sense and in context in both questionnaires, the proportion of those informants who felt that this verb referred to a risky, difficult or dangerous thing had changed significantly in the course of four years. While in 2010, $50 \%$ of university students felt that the neologism referred to a risky, difficult or dangerous thing, in 2014, only $31 \%$ of university students said this. In the case of secondary school students, another trend can be observed: while in $2010,24 \%$ of them referred to the difficult circumstances concerning the meaning of bevállal, in 2014, 70\% of them felt that this verb referred to dealing with difficulties, which implies that more research needs to be carried out in this area. It follows from the results that the features of undertaking something risky/difficult/dangerous occurs in the semantic structure of the neologism bevállal. Analogously to the analyses in the case of becéloz and betámad, Conceptual Integration Theory can be helpful if we want to represent the structure of this neologism graphically.

In the case of bevállal, we have to deal with more than one metaphor in understanding the neologism. It is significant that vállal, elvállal, felvállal and bevállal are derived from the Hungarian noun 'shoulder' (váll). With the occurrence of be with this stem, the CONTAINER METAPHOR occurs again, but - just as in the case of betámad above - in connection with human feelings and the soul, in order to emphasize the enthusiasm of the agent, which plays an important role in the elaboration of the new sense of the verb. These features of the two input spaces (viz. the two different ideas that can occur in the language users' mind when they use or hear the word, cf. informants' answers in the questionnaires) are very different from each other in meaning and function. Consequently, it seems to be sensible to represent a generic space. This 
space is usually facultative, but in the case of bevállal it can help "solve", "sublimate", or "melt together" the metaphors that have roles in making up the meaning of bevállal. To sum up, souL IS A CONTAINER METAPHOR, viz. when someone feels that they are capable of undertake something as if it was put on their shoulders, as well as the importance of the starting point and totality emphasized by be result in the new meaning and give birth to those features that differentiate bevállal from elvállal or felvállal. The meaning of the neologism bevállal can graphically be represented in Conceptual Integration Theory as it follows:

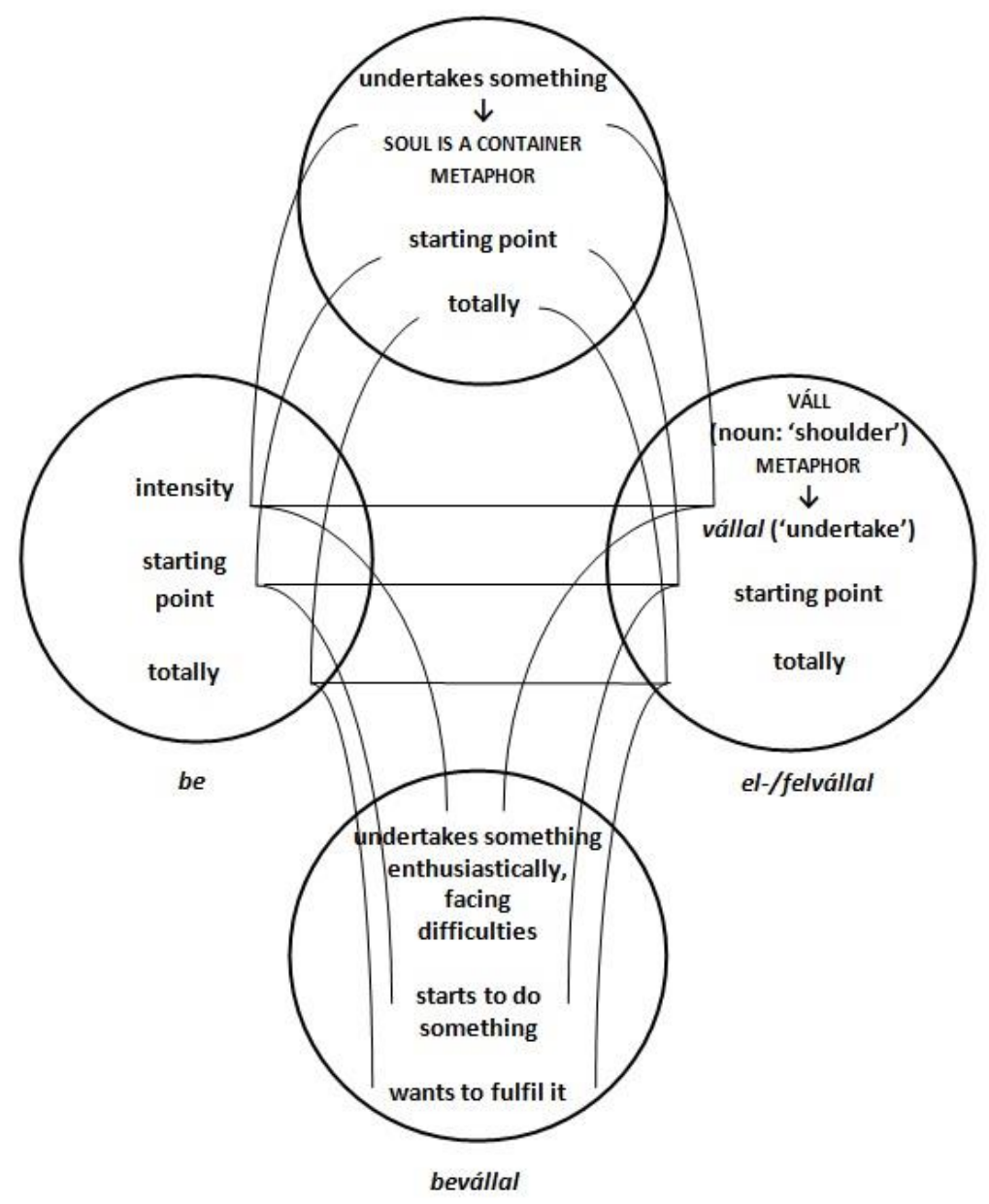

Figure 4: Blend of bevállal

As it can be seen in Diagram 6, in 2010, among those informants who answered the question concerning liking/disliking bevállal, elementary students and university students wrote that they liked the verb, but only in small proportions (4\% of elementary students and $9 \%$ of university students). 


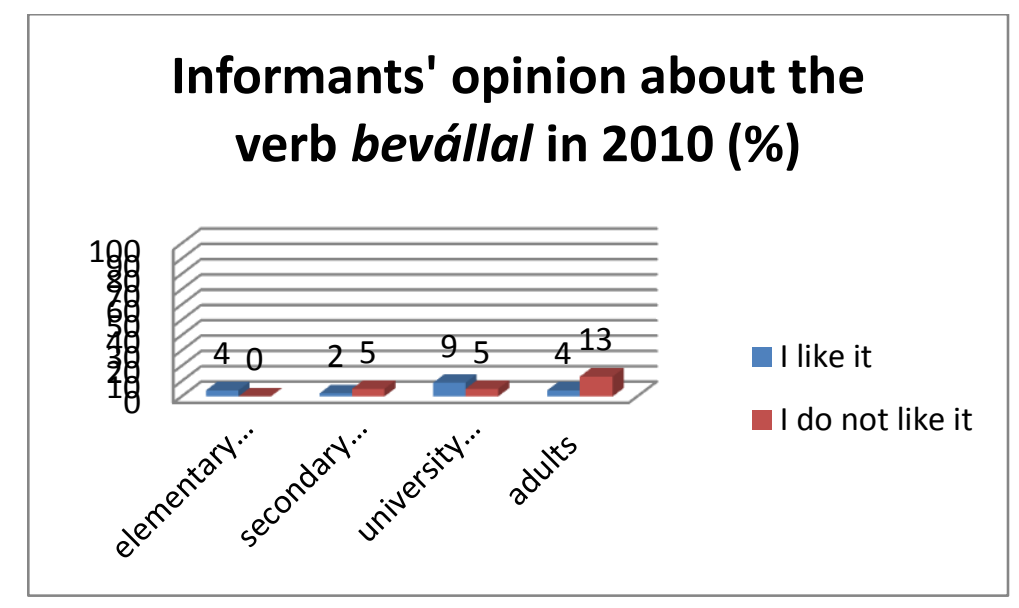

Diagram 6: Opinions about bevállal

In contrast to the above findings, in the 2014 questionnaire $19 \%$ of university students and $11 \%$ of secondary school students said that they found this verb 'natural' and they did not feel that it was unusual in the context in which it was cited, which may indicate that bevállal has taken root in present-day Hungarian. Nevertheless, $44 \%$ of university students and $4 \%$ of secondary school students referred to the slang, informal, or otherwise 'loose' style of bevállal, which seems to mean that although it is now common it is still felt by many to be substandard.

To conclude, the ancient prefix be, with frequent occurrence in present-day Hungarian, has gained new functions, which arise logically from the prefix's general characteristics. While not everyone judges the neologisms becéloz, betámad, and bevállal right, they are undeniably in common use today. The present preliminary study focused on these three neologisms with the prefix be at a given point in time, but in the process of language change, these new meanings will likely undergo further change, as we can examine a synchronic segment of language use. It remains a task for the future to gather more data and investigate the changes in the case of these neologisms in order to draw further inferences about them and their use.

\section{Works Cited}

Benczes, Réka. 2006. Creative Compounding in English. The Semantics of Metaphorical and Metonymical Noun-Noun Combinations. Amsterdam - Philadelphia: John Benjamins Publishing Company.

Coulson, Seana and Todd Oakley. 2003. "Metonymy and Conceptual Blending." In Metonymy and Pragmatic Inferencing. Eds., Klaus-Uwe Panther and Linda L. Thornburg.

Amsterdam/Philadelphia: John Benjamins Publishing Company, 51-80.

Croft, William. 2000. Explaining Language Change. An Evolutionary Approach. Harlow - New York: Longman.

Fauconnier, Gilles. 1994. Mental Spaces. Cambridge: MIT Press/Cambridge UP.

Fauconnier, Gilles and Mark Turner. 1998. Conceptual Integration Networks. Cognitive Science 22/2: 133-187. 
Sólyom, Réka. "Semantic Features of Hungarian Neologisms With the Prefix Be: Analysis of Some Frequently Used Verbs (e.g., bevállal)." Hungarian Cultural Studies. e-Journal of the American Hungarian Educators Association, Volume 7 (2014): http://ahea.pitt.edu DOI: 10.5195/ahea.2014.148

Grady, Joseph E., Todd Oakley, and Seana Coulson. 1999. "Blending and Metaphor.” In Metaphor in Cognitive Linguistics. Eds., Gerard Steen and Raymond Gibbs. Philadelphia: John Benjamins, 101-125.

Keller, Rudi. 1985. “Towards a Theory of Linguistic Change.” In Linguistic Dynamics: Discourses, Procedures and Evolution (Research in Text Theory vol. 9). Ed., Thomas T. Ballmer. Berlin, New York: Walter de Gruyter, 211-237.

Kiefer, Ferenc and Mária Ladányi. 2000. "A be igekötö kapcsolódási mintái ['Connecting Patterns of the prefix Be'].” In Strukturális magyar nyelvtan 3. Morfologia. Ed., Ferenc Kiefer. Budapest: Akadémiai Kiadó.

Kövecses, Zoltán \& Günther Radden. 1998. "Metonymy: Developing a Cognitive Linguistic View." Cognitive Linguistics 9/1: 37-77.

Kövecses, Zoltán. 2005. A metafora. Gyakorlati bevezetés a kognitív metaforaelméletbe. ['Metaphor. A Practical Introduction to the Cognitive Theory of Metaphor'] Budapest: Typotex Kiadó.

- 2010. Metaphor. A Practical Introduction. Second Edition. Oxford - New York: Oxford University Press.

Kövecses, Zoltán and Réka Benczes. 2010. Kognitív nyelvészet ['Cognitive Linguistics'] Budapest: Akadémiai Kiadó.

Ladányi, Mária. 2007. Produktivitás és analógia a szóképzésben: elvek és esetek ['Productivity and Analogy in Word Formation: Principles and Case Studies']. Budapest: Tinta Könyvkiadó.

Lakoff, George and Mark Johnson. 1980. Metaphors We Live By. Chicago and London: University of Chicago Press.

Langacker, Ronald W. 1987. Foundations of Cognitive Grammar. Vol. I. Theoretical Prerequisites. Stanford, California: Stanford University Press.

Lehrer, Adrienne. 2003. "Understanding Trendy Neologisms." Rivista di Linguistica 15/2: 369382.

Panther, Klaus-Uwe and Linda L. Thornburg. 2003. "On the Nature of Conceptual Metonymy." In Metonymy and Pragmatic Inferencing. Eds., Klaus-Uwe Panther \& Linda L. Thornburg. Amsterdam/Philadelphia: John Benjamins Publishing Company, 1-20.

Pátrovics, Péter. 2002. "Néhány gondolat a magyar igekötők eredetéről, valamint aspektus- és akcióminőség-jelölő funkciójuk (ki)alakulásáról ['Some Thoughts on the Origin of the Hungarian Prefixes and the Evolution of their Aspect and Aktionsart Roles']." Magyar Nyelvör 126/4: 481-489.

Pusztai, Ferenc. ed. 2003. Magyar értelmezö kéziszótár ['The Concise Dictionary of the Hungarian Language']. Budapest: Akadémiai Kiadó.

J. Soltész, Katalin. 1959. Az ösi magyar igekötök (meg, el, ki, be, fel, le) [The Ancient Hungarian Verbal Prefixes (meg, el, ki, be, fel, le)]. Budapest: Akadémiai Kiadó.

Sólyom, Réka. 2012a. "Becéloz, betámad, bevállal - be igekötős neologizmusaink szemantikájáról ['Becéloz, betámad, bevállal - on the Semantics of Hungarian Neologisms with the prefix Be']." In Doktoranduszok a nyelvtudomány útjain. A 6. Félúton Konferencia, ELTE BTK, 2010. október 7-8. Ed., Andrea Parapatic. Budapest: ELTE Eötvös Kiadó, 203213.

http://linguistics.elte.hu/studies/fuk/fuk10/BE\%20igek\%F6tos\%20neologizmusaink_S\%D3 LYOM.pdf 
Sólyom, Réka. "Semantic Features of Hungarian Neologisms With the Prefix Be: Analysis of Some Frequently Used Verbs (e.g., bevállal)." Hungarian Cultural Studies. e-Journal of the American Hungarian Educators Association, Volume 7 (2014): http://ahea.pitt.edu DOI: 10.5195/ahea.2014.148

2012b. "Fórumszövegek vizsgálata: neologizmusok elemzése a szemantikai felépítés és a stílus szociokulturális rétegzettségének vonatkozásában ['Examination of Forum Texts: the Analysis of Neologisms in relation to Semantic Structure and the Socio-Cultural Factors of Style']." In A stílus szociokulturális tényezői. Kognitív stilisztikai tanulmányok. Eds., Szilárd Tátrai and Gábor Tolcsvai Nagy. Budapest: Eötvös Loránd Tudományegyetem. 263-299. - 2013. "A Study of Forum Texts: Semantic and Stylistic Analyses of Hungarian Neologisms." Studia Linguistica Hungarica (Formerly Annales Sectio Linguistica). The Linguistic Journal of the Faculty of Humanities, Eötvös Loránd University, Department of Contemporary Hungarian Linguistics. 28: 149-165.

-_-_-- 2014. A mai magyar neologizmusok szemantikája. Nyelvtudományi értekezések 165. sz. [Semantics of Present-day Hungarian Neologisms]. Budapest: Akadémiai Kiadó. T. Somogyi, Magda. 2003. Az újabb be igekötős igék és az ifjúsági nyelv ['Recent Verbs with the Prefix be and the Language of Young People']. In Köszöntö könyv Kiss Jenö 60. születésnapjára. Eds., Mihály Hajdúand Borbála Keszler. Budapest: ELTE, 371-375.

Szathmári, István. 2004. Stilisztikai lexikon: stilisztikai fogalmak magyarázata szépirodalmi példákkal szemléltetve [A Dictionary of Stylistics: Explanations of Stylistic Concepts Illustrated from Literature]. Budapest: Tinta Könyvkiadó.

Tolcsvai Nagy, Gábor. 2010. Kognitív szemantika [Cognitive Semantics]. Nyitra: Europica varietas.

—. 2013. Bevezetés a kognitív nyelvészetbe [An Introduction to Cognitive Linguistics]. Budapest: Osiris Kiadó.

Van Gorp, Hendrik et al., eds. 2001. Dictionnaire des Termes Littéraires [A Dictionary of Literary Terms]. Paris: Honoré Champion Éditeur.

Wales, Katie. 1990. A Dictionary of Stylistics. London and New York: Longman.

Wilpert, Gero von. 1989. Sachwörterbuch der Literatur [A Technical Dictionary of Literature]. Stuttgart: Alfred Kröner Verlag. 